\title{
E. Richard, Christopher G. Moran, Theerachai Apivatthakakul (eds): AO principles of fracture management 2 vols., third edition
}

\author{
Thieme Verlag, New York, Stuttgart, Delhi, Rio de Janeiro, 2017, 1120 pp, 2500 figs, \\ 280,00 mm, Hardcover (GEB), EUR (D) 419,99 EUR (A) 431,80 CHF 483,00, ISBN: 978-3-13- \\ 242309-1
}

Pierre Kehr ${ }^{1}$

Received: 6 May 2018 / Accepted: 20 May 2018 / Published online: 4 June 2018

๑) Springer-Verlag France SAS, part of Springer Nature 2018

This true monument Co-writing by 61 international authors constitutes the bible of the AO. Volume 1 is dedicated to the principles, volume 2 with the specific fractures.

First of all are pointed out philosophy AO with the biology and the mechanisms of cure of the fractures, the biotechnology of the implants and especially classification AO of the fractures and the lesions of soft tissues.

Decision making and planning are detailed for the fractures diaphyseal on the one hand, the articular fractures on the other hand. Reduction and fixing are then presented, either with absolute stability, or relative (external fixer, for example).

The following chapters make ravel the multiple traumas, the opened fractures, the losses of soft fabrics, the fractures pediatric, the postoperative disease prevention antibiotic and thromboembolic, care, the fractures of the elderly people, the risks of the irradiation of the imagery and finally the complications.
Volume 2 is devoted to the fractures according to the area anatomical, on the basis of the shoulder and finishing by ankle and the foot. The fractures of the spine are evoked only in the chapters of the fractures of the osteoporotic elderlies.

A glossary clarifying the various terms used by the authors and a thick index, respectively, allow an easier reading and fast entries for the reader who wants to go directly on a precise point.

With its 2500 illustrations, two volumes are magnificently illustrated.

This work must be present in the library of any experienced traumatologist or trainees.

\section{Compliance with ethical standards}

Conflict of interest The author declares that he has no competing interests.
Pierre Kehr

pierre.kehr@gmail.com

1 Strasbourg, France 